\title{
Suicides in Mood Disorders in Psychiatric Settings in Nordic National Register-Based Studies
}

\author{
Erkki T. Isometsä* \\ Department of Psychiatry, University of Helsinki and Helsinki University Hospital, Helsinki, Finland
}

\section{OPEN ACCESS}

Edited by:

Matthias Jaeger,

Psychiatrie Baselland,

Switzerland

Reviewed by:

Xenia Gonda,

Semmelweis University,

Hungary

Helinä Hakko,

Oulu University Hospital,

Finland

*Correspondence:

Erkki T. Isometsä

erkki.isometsa@helsinki.fi;

erkki.isometsa@hus.fi

Specialty section:

This article was submitted to

Public Mental Health,

a section of the journal

Frontiers in Psychiatry

Received: 08 April 2020

Accepted: 08 July 2020

Published: 23 July 2020

Citation:

Isometsä ET (2020) Suicides in

Mood Disorders in Psychiatric

Settings in Nordic National

Register-Based Studies.

Front. Psychiatry 11:721.

doi: 10.3389/fpsyt.2020.00721
Objective: Although risk factors for nonfatal suicidal behavior in mood disorders have been vastly investigated, rate and risk factors of suicide deaths are less well known. Extensive health care and other population registers in the Nordic countries (Denmark, Finland, Iceland, Norway, and Sweden) allow national-level studies of suicide rates and risk factors. This systematic review examined Nordic studies of suicide in mood disorders.

Methods: National Nordic studies published after 1.1.2000 reporting on suicide mortality or relative risk in diagnosed unipolar depression or bipolar disorder treated in psychiatric settings; temporal variations in suicide risk after discharge, or risk factors for suicide were systematically reviewed.

Results: Altogether 16 longitudinal studies reported on rate and risk of suicide in depression. They found $2 \%-8 \%$ of psychiatric inpatients with depression to have died by suicide. However, in Finland suicide risk among depressive inpatients halved since the early 1990s. Nine studies investigated suicide risk in bipolar disorder, finding 4-8\% of patients having died by suicide in long term. The relative risk of suicide was consistently found extremely high (SMR > 100) during the first weeks postdischarge, declining steeply over time to approximately SMR of five after five years. Male gender, preceding suicide attempts, high severity of depression and substance abuse were found risk factors for suicide in depression, with only minor gender differences in risk factors, but major differences in lethal methods. Three studies investigated risk factors for suicide in bipolar disorder, finding male gender, preceding suicide attempts, and depressive episodes and psychiatric comorbidity to be associated with risk.

Conclusions: Overall, of psychiatric inpatients with depressive of bipolar disorders in the Nordic countries, $2 \%-8 \%$ have died by suicide in the last few decades, but current rates may be lower. Suicide risk is approximately similar or somewhat higher among patients with bipolar disorder, risk factor studies of whom are fewer. Risk of suicide is remarkably high immediately after discharge, and higher among males than females, those with preceding suicide attempts, high severity of depression, or concurrent substance abuse. Generalizability of findings from these Nordic studies to other countries need to be investigated, and their methodological limitations understood.

Keywords: suicide, mortality, incidence, depression, bipolar disorder, register, risk factor, systematic review 


\section{INTRODUCTION}

Suicide is an important cause of death worldwide, and about $1.5 \%$ of all deaths are by suicide (1). About half of all suicides have been found to have suffered from mood disorders in psychological autopsy studies (2-5). Therefore, for suicide prevention overall, monitoring suicide mortality, knowledge of risk factors for suicide, and provision of adequate treatment for patients with mood disorders are central tasks.

Although risk factors for nonfatal suicidal behavior in mood disorders have been vastly investigated, rate and risk factors of suicide deaths are less well known (6). Suicides are rare events, and investigating their rate and risk factors necessitates massive patient samples. Over decades of work in this field, advances have been made in the knowledge of risk factors for suicide, and this information has been condensed into risk estimates in important meta-analyses $(7,8)$. However, as such documents reveal, for many important risk factors uncertainty prevails due to limitations of the samples available. Even though research on nonfatal suicidal acts can form an important proxy for studies of suicide deaths and complement view of significant risk factors, studies of suicide deaths are needed for confirming generalizability of findings between the populations (6). Early estimates for accumulating suicide mortality in major mood disorders were as high as 19\% (9). However, already twenty years ago Bostwick and Pankratz (10) suggested an epidemiologically conceivable gradient of lifetime suicide risk (case fatality prevalence) from general population $0.5 \%$ to $8.6 \%$ in suicidal psychiatric inpatients. Nevertheless, scarcity of representative contemporary diagnosis-specific data is a major problem, despite a great need for monitoring rates of suicide in these central patient groups.

Due to availability of extensive health care and other population registers in the Nordic countries-Denmark, Finland, Iceland, Norway and Sweden-national-level studies of suicides in mood disorders are feasible (11), and can provide unbiased, generalizable information on suicide rates and risk factors. These countries share similarities in terms of population, culture, health care and social services, and health-related findings are in general comparable, with some but usually relatively small differences $(12,13)$. For purposes of this review, the most relevant difference has been higher male suicide mortality in Finland, which has markedly declined and approached, but not yet reached the general Nordic level (14).

The aim of this systematic review was to examine published literature on national-level or, in the absence of national-level data, large regional studies of suicide in psychiatric patients with unipolar and bipolar mood disorders from the Nordic countries from the year 2000 onwards.

\section{METHODS}

\section{Inclusion and Exclusion Criteria, Literature Searches and Collection of Relevant Papers}

This review included nationally representative, register-based studies reporting on suicide mortality of diagnosed psychiatric patients with unipolar depression or bipolar disorder. Studies from the Nordic countries were included, if they were (a) based on national health care registers containing diagnostic data on patients' with psychiatric hospitalizations and/or treatment as psychiatric outpatients; (b) concerned patients with ICD-10 codes F30-31 (manic episode or bipolar affective disorder) and F32-33 (depressive episode and recurrent depressive disorder), or similar diagnoses in the earlier versions of the ICD (ICD-9 or ICD-8); and (c) cause of death was reported based on linkage to nationally representative registers of official causes of death.

Studies were excluded if they were (a) not nationally representative, (b) did not contain diagnostically specific data on suicides in unipolar or bipolar mood disorders or the two groups combined, (c) classification of death as a suicide was not based on the official classification of causes of death in the country, or (d) contained exclusively primary health care patients. However, regionally representative data was considered, if nationally representative data was unavailable, and the study otherwise fulfilled the criteria above.

The author identified relevant studies from the PubMed published after 1.1 .2000 by searching (on December $16^{\text {th }}, 2019$ ) using terms "suicide AND register* AND (depression OR bipolar disorder) AND [name of country]. These searches resulted in locating 169 potentially relevant abstracts (listed countrywise in the Figure 1). The author also contacted three Norwegian and two Icelandic authors to locate relevant papers, and sought references from other relevant papers. Of all these reports, total 16 were included as relevant for this review (see Figure 1). The remaining 153 were excluded as not nationally representative, or not containing diagnostically specific data on suicides in unipolar or bipolar mood disorders in psychiatric care. No primary health care studies emerged, so no studies were excluded as nonpsychiatric.

\section{Classification of Relevant Papers}

The publications were divided into those reporting on (a) suicide mortality or relative risk in diagnosed unipolar depression treated in psychiatric settings; (b) such findings pertaining to diagnosed bipolar disorder; (c) temporal variations in suicide risk after discharge; (d) risk factors for suicide in unipolar depression or (e) bipolar disorder.

The author has organized the relevant 16 reports into Tables 1-3. As many studies reported on both unipolar and bipolar mood disorders, they are included in both contexts. The author extracted from the reports information case fatality prevalence, cumulative incidence, standardized mortality ratio (SMR) or other measures of absolute and relative mortality, plus information on several risk factors (gender, preceding suicide attempts, severity of illness at baseline, presence of psychotic features, comorbid substance abuse or dependence, and other). No statistical analyses were conducted.

\section{RESULTS}

\section{Suicide Deaths in Unipolar Depression}

Altogether eleven Danish (15-19), Finnish (20, 21), Norwegian (22), and Swedish (23-25) studies reported on rate and risk of suicide in unipolar depression (Table 1). They found between $2 \%$ and $8 \%$ of 


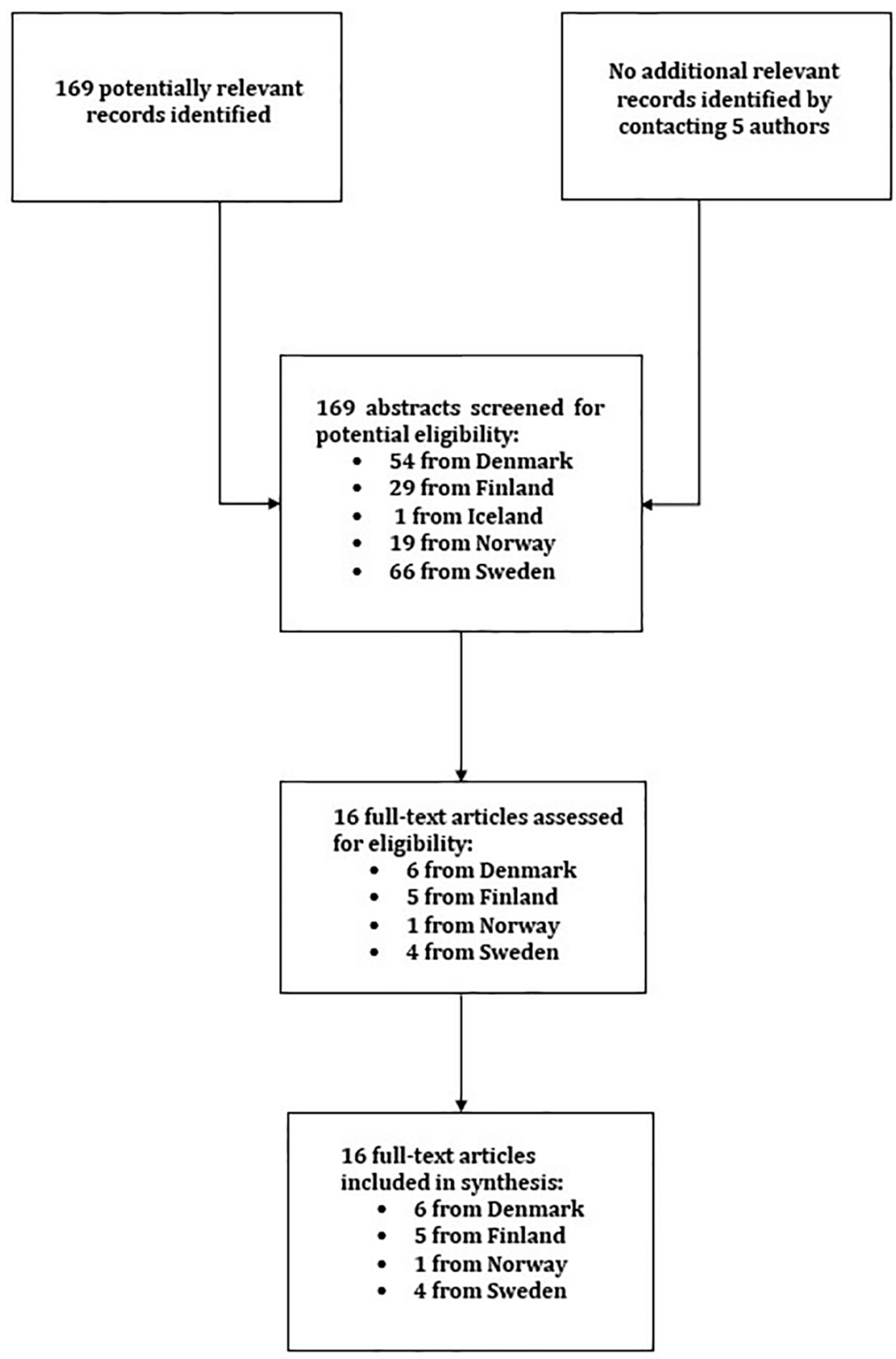

FIGURE 1 | Flow chart of systematic literature search.

psychiatric inpatients with depression to have died by suicide. The Danish study by Nordentoft et al. (17) was the most long-term (median follow-up 18 years), finding about $7 \%$ of males and $4 \%$ to have died by suicide. However, a Finnish national study (21) demonstrated decline of hazard ratio for suicide to 0.48 among depressive inpatients since the early 1990s (Table 1).

\section{Suicide Deaths in Bipolar Disorder}

Eight studies reported on suicide risk in bipolar disorder (Table 2). Three of them were Danish (15-17), two Finnish $(26,27)$ and one from Norway (22) and three from Sweden $(23,25,28)$. In general, these studies found $4 \%$ to $8 \%$ of their bipolar patients having died by suicide. The study of Hansson et al. (28) was included, even though it is based on a national Swedish quality register (BipoläR), from which patients can (by law) opt out. This study found significantly lower suicide mortality in 2004-2014 among patients included (Table 2).

\section{Temporal Variations in Suicide Risk After Discharge}

For both unipolar and bipolar patients, the relative risk of suicide was consistently found extremely high $($ SMR > 100) during the 
TABLE 1 | Suicide mortality in nationally representative register studies of unipolar depression in the Nordic countries.

\begin{tabular}{|c|c|c|c|c|c|}
\hline $\begin{array}{l}\text { Country } \\
\text { and } \\
\text { reference }\end{array}$ & Study Design & $\begin{array}{l}\text { Ns of cohort and suicides with } \\
\text { depression and registers used }\end{array}$ & Follow-up period & $\begin{array}{l}\text { Suicide mortality/relative } \\
\text { suicide risk ( } 95 \% \text { c.I.)* }\end{array}$ & Notes \\
\hline
\end{tabular}

\section{Denmark}

Høyer

et al. (15) for affective disorder in

Denmark in 1973-1993

Qin and Nested case-control

Nordentoft study of postdischarge

(16) suicides in Denmark in

Nordentoft Prospective study of et al. (17) incident suicides among Danes born 1955-1991 to end of 2006

Leadholm Prospective cohort of et al. (18) Danish in-patients with severe psychotic or nonpsychotic depression 1994-2010.

Laursen et Prospective national al. (19) Danish cohort 1995-2013 1981-1997

54,103 inpatients with affective disorder in the Danish Psychiatric Case Register,

3,127 suicides in National

Register of Causes of Death

423,128 population controls from Up to 16 years the Integrated Database for Labour Market Research; 21,169 suicides in Cause of Death Register, 2,736 with affective disorders at hospitalization in the Danish Psychiatric Central Register 176,347 mental health patients in Up to 36 years (median the Danish Psychiatric Central Register,

46,233 with depression,

709 suicides in the Danish Registers of Causes of Death 34,671 in- or out-patients in the Danish Central Psychiatric Register,

755 suicides in the Danish Cause of Death Register 5,103,699 population;

554,987 with depression in the Danish Psychiatric Central Register and Danish National Patient Register; linked to Danish Registry of Causes of Death, $\mathrm{N}$ suicides not reported

Finland

Suominen Prospective cohort of et al. (20) Finnish inpatients hospitalized for depression and attempted suicide between 1996-2003

Aaltonen Prospective cohort of et al. (21) Finnish first-time inpatients with depression in 1991-2011; comparison of cohorts of 1991-1995 vs. 19962000 vs. $2001-2005$ vs 2006-2011

\section{Norway}

Høye et al. Prospective cohort of (22) maximum 24 years inpatients with mood disorders in two northernmost counties in Norway in 1980-2012
1,820 inpatients in the National Hospital Discharge Register, 106 suicides in cause of death register of the Statistics Finland

56,826 inpatients in the Finnish Hospital Discharge Register, 2,587 suicides in Statistic Finland's register on causes of death.

Total 2,501 mood disorder patients in the University Hospital of North Norway and total 79 suicides in the Norwegian Cause of Death Registry; 1,656 with major depressive disorder and 47 suicides
Up to end of 1993 , maximum up to 21 years

18 years)

\section{Up to 17 years}

$2.1 \%$ nonpsychotic, 2.3\% psychotic depression

Period 1995-2013

Mortality rate ratio (MRR) 4.66 (4.53-4.79) for suicides and accidents

Up to 8 years (end of 2003, mean 4.2 years

Up to end of 2014 (median 10.7 years)

$6 \%$ died by suicide, crude incidence 1,390 per 100,000 patient-years

Cumulative risk 6.13\% (5.80$6.46) ; 8.4 \%$ (8.00-9.27) in men, $4.14 \%$ in women (3.834.45).

Hazard ratios declined stepwise from 1.0 in 19911995 to $0.48(0.43-0.55)$ in 2006-2011.

Up to end of 2012 (total 13,766 person-years)

SMR for suicide 23.9 (18.031.8); in men 24.0 (17.0-33.9), in women 23.7 (14.3-39.4)
Relative risks presented for all diagnostic subgroups, but their specific numbers of patients and suicides not reported.

Focus in postdischarge suicides, unipolar and bipolar disorders not differentiated

Out-patient visits included from 1995 to 2006

Focus in severe depression and role of psychotic features for risk of suicide. Outpatients included from 1995 onwards.

Estimated reduced life expectancy 14.0 years in males and 10.1 years in females. Inpatients, plus outpatients from 1995 onwards.

Cohort comprised only inpatients with depression, who had attempted suicide at index hospitalization; a highrisk population

Reduction in risk despite halving of inpatient days in Finland between 1991 and 2011.

A high suicide mortality-area in Norway 
TABLE 1 | Continued

\begin{tabular}{|c|c|c|c|c|c|}
\hline $\begin{array}{l}\text { Country } \\
\text { and } \\
\text { reference }\end{array}$ & Study Design & $\begin{array}{l}\text { Ns of cohort and suicides with } \\
\text { depression and registers used }\end{array}$ & Follow-up period & $\begin{array}{l}\text { Suicide mortality/relative } \\
\text { suicide risk (95\% c.I.)* }\end{array}$ & Notes \\
\hline \multicolumn{6}{|l|}{ Sweden } \\
\hline $\begin{array}{l}\text { Ösby et al. } \\
\text { (23) }\end{array}$ & $\begin{array}{l}\text { Prospective cohort of } \\
\text { unipolar depressive } \\
\text { inpatients in Sweden in } \\
\text { 1973-1995 }\end{array}$ & $\begin{array}{l}39,182 \text { unipolar patients in the } \\
\text { Swedish psychiatric inpatient } \\
\text { register; } 2,045 \text { suicides in the } \\
\text { cause of death register of } \\
\text { Statistics Sweden. }\end{array}$ & $\begin{array}{l}\text { Up to end of } 1995, \\
\text { mean follow-up } 9.37 \\
\text { years (SD } \pm 6.58 \text { ) in men } \\
\text { [1052 suicides } / 148372 \\
\text { person-years], } 10.68 \\
\text { years (SD } \pm 6.65) \text { in } \\
\text { women [993 suicides/ } \\
\text { 249366person-years] }\end{array}$ & $\begin{array}{l}\text { SMR in men } 20.9 \text { (19.7-22.2), } \\
\text { SMR in women } 27.0 \text { (25.3- } \\
28.7)\end{array}$ & $\begin{array}{l}\text { Suicides as part of overall } \\
\text { mortality; SMRs rather than } \\
\text { cumulative incidence }\end{array}$ \\
\hline $\begin{array}{l}\text { Tidemalm } \\
\text { et al. (24) }\end{array}$ & $\begin{array}{l}\text { Prospective cohort study } \\
\text { of Swedes admitted to } \\
\text { hospital in 1973-1982 for } \\
\text { attempted suicide }\end{array}$ & $\begin{array}{l}39,695 \text { people hospitalized for } \\
\text { attempted suicide in the Swedish } \\
\text { hospital discharge register, } \\
\text { including 1,043 patients with } \\
\text { bipolar or unipolar disorder with } \\
271 \text { suicides during follow-up in } \\
\text { the cause of death register. }\end{array}$ & $\begin{array}{l}\text { Follow-up to } 2003 \text { (for } \\
21-31 \text { years) }\end{array}$ & $\begin{array}{l}\text { Adjusted hazard ratio for } \\
\text { suicide in men } 3.5 \text { (3.0-4.2), in } \\
\text { women } 2.5 .(2.1-3.0)\end{array}$ & $\begin{array}{l}\text { Cohort comprised only } \\
\text { patients having attempted } \\
\text { suicide. Two-thirds (68\%) of } \\
\text { the hospitalized patients were } \\
\text { not given a psychiatric } \\
\text { diagnosis and comprised the } \\
\text { reference group of the study. }\end{array}$ \\
\hline $\begin{array}{l}\text { Haglund } \\
\text { et al. (25) }\end{array}$ & $\begin{array}{l}\text { Prospective cohort of all } \\
\text { discharges of inpatients in } \\
\text { Sweden in 1973-2009 }\end{array}$ & $\begin{array}{l}\text { Overall 2,883,088 discharges in } \\
\text { the Swedish National Patient } \\
\text { Register and 3,695 suicides in the } \\
\text { Cause of Death Register; } 447,254 \\
\text { and } 1,177 \text { with depression, } \\
\text { respectively }\end{array}$ & $\begin{array}{l}\text { First } 30 \text { days after } \\
\text { discharge }\end{array}$ & $\begin{array}{l}\text { Suicide rate } 3,600 \text { ( } 3390- \\
3800 \text { ) per } 100,000 \text { patient- } \\
\text { years in depression }\end{array}$ & $\begin{array}{l}\text { Focus in immediate first- } \\
\text { month postdischarge } \\
\text { suicides, the period with } \\
\text { highest risk }\end{array}$ \\
\hline
\end{tabular}

*Incidence rates converted to per 100,000 patient years for comparability. SMR, standardized mortality ratio.

first weeks postdischarge (Tables 1 and 2), declining then over time to approximately SMR of five after five years the last hospitalization $(16,25,26)$.

\section{Risk Factors for Suicide in Unipolar Depression}

The five studies reporting on risk factors for suicide $(17,18,20$, 29 , 30) consistently found male gender, preceding suicide attempts, high severity of depression and substance abuse risk factors for depression in long term. Aaltonen et al. (30) in Finland investigated also gender differences in thirteen risk factors, finding only small differences in them, but major differences in lethal methods used. A Danish study (18) focused on psychotic vs. severe nonpsychotic depressions, finding no significant difference in risk (Table 3).

\section{Risk Factors for Suicide in Bipolar Disorder}

Risk factors for suicide in bipolar disorder were reported by three studies $(17,26,28)$, which found male gender, preceding suicide attempts, and hospitalization for depressive and mixed episodes to associated with risk (Table 3). The study of Hansson et al. (28) was included, even though it is based on a national Swedish quality register (BipoläR), from which patients can opt out. In this study the researchers were able to investigate role of 20 putative risk factors for suicide, documenting role of male gender, living alone, criminal conviction, previous year depressive episodes, psychiatric comorbidity (substance abuse, anxiety or personality disorders) and severity indicators of psychiatric history (inpatient treatment, involuntary commitment) as risk factors (Table 3).

\section{DISCUSSION}

\section{Main Findings}

Overall, findings of the available national diagnosis-specific studies from Denmark, Finland and Sweden were broadly consistent. Of psychiatric inpatients with depressive of bipolar disorders in the last few decades, $2 \%-8 \%$ have died by suicide in long term. However, these estimates generally concern only psychiatric patients ill enough to be hospitalized. Furthermore, suicide mortality has markedly declined among depressive inpatients in Finland after the early 1990s. Given decline in overall suicide mortality in all of the Nordic countries, suicide mortality in mood disorder patients has likely declined in all of them. Suicide risk is approximately similar or somewhat higher among patients with bipolar disorder, of whom differences in mortality between type I or II patients remain obscure.

\section{Temporal Variation in Risk}

Rate of suicides is very strongly related to phase of illness and treatment. Incidence of suicide in the first weeks after discharge from a psychiatric hospital has been consistently found to be very high, even over hundred times that of the general population. In the Swedish national study from 1973 through 2009 by Haglund et al. (25) suicide rate among depressive inpatients in the first month after discharge was 3,600 and among bipolar inpatients 1,740 per 100,000 patient-years. Findings from Denmark (16) and Finland (26) are broadly similar, and in accordance with the broader international literature $(31,32)$. Although the postdischarge treatment phase is a well-known period of high risk of suicide across diagnostic groups, the documented role of illness factors need to be noted. Haglund et al. (25) found marked 
TABLE 2 | Suicide mortality in bipolar disorder in Nordic national-level register-based studies.

\begin{tabular}{|c|c|c|c|c|c|}
\hline $\begin{array}{l}\text { Country } \\
\text { and } \\
\text { reference }\end{array}$ & Study Design & $\begin{array}{c}\text { Ns of cohort and suicides with } \\
\text { bipolar disorder }\end{array}$ & Follow-up period & $\begin{array}{l}\text { Suicide mortality/relative } \\
\text { suicide risk }(95 \% \text { c.l. })^{*}\end{array}$ & Notes \\
\hline
\end{tabular}

\section{Denmark}

Høyer

et al. (15)

All first-time admissions for

affective disorder in

Denmark in 1973-1993

Qin and Nested case-control study

Nordentoft of postdischarge suicides in

(16) Denmark in 1981-1997

Nordentoft Prospective study of

et al. (17) incident suicides among

Danes born 1955-1991 to

end of 2006

\section{Finland}

Isometsä

et al. (26)

Prospective cohort of all

hospitalizations for bipolar

disorder in Finland in 1987-

2003.

Toffol et al. Prospective cohort of

(27) inpatients hospitalized for bipolar disorder and attempted suicide between 1996 and 2003

\section{Norway}

Høye et al. Prospective cohort of

\section{inpatients with mood} disorders in two northernmost counties in Norway in 1980-2012

\section{Sweden}

Ösby et al. Prospective cohort of (23) bipolar inpatients in Sweden in 1973-1995

Hansson Prospective cohort study et al. (28) based on the Swedish National Quality Register for Bipolar Affective Disorder (BipoläR) and suicide deaths in 2004-2014.

Haglund Prospective cohort of all et al. (25) discharges of inpatients in Sweden in 1973-2009
54,103 inpatients with affective disorder in the Danish Psychiatric Case Register,

3,127 suicides in National Register of Causes of Death

423,128 population controls the Integrated Database for Labour Market Research;

21,169 suicides in Cause of Death Register, 2,736 with affective disorders at hospitalization in the Danish Psychiatric Central Register. 176,347 mental health patients in the Danish Psychiatric Central Register,

5,927 with bipolar disorder,

175 suicides in the Danish

Registers of Causes of Death.

Total 52,747 hospitalizations in the Finnish Hospital Discharge

Register, 466 suicides in the cause of death register of Statistics Finland.

826 inpatients in the Hospital Discharge Register, 50 suicides in the causes of death register of the Statistics Finland

Total 2,501 mood disorder patients in the University Hospital of North Norway and total 79 suicides in the Norwegian Cause of Death Registry; 845 with bipolar disorder and 32 suicides

15,386 bipolar inpatients in the Swedish psychiatric inpatient register, 672 suicides in the cause of death register of Statistics Sweden.

12,850 bipolar psychiatric outpatients in the BipoläR, 90 suicides in Cause of Death Register

\section{Up to 36 years (median 18} years)

Up to end of 1993, maximum up to 21 years

Up to 16 years

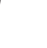

SMR in bipolar disorder 18.09 (16.32-20.07). Risk highest during the first postdischarge year.

Sharply declining trends of adjusted risk ratio from first postdischarge week to $>5$ years: from 218.8 to 4.8 in men, and 1976.5 to 4.9 in women

Cumulative incidence $7.77 \%(6.01-10.05)$ in men, $4.78 \%$ (3.48-6.56) in women
Relative risks presented for all diagnostic subgroups, but their specific numbers of patients and suicides not reported.

Focus in postdischarge suicides, unipolar and bipolar disorders not differentiated

Out-patient visits included from 1995 to 2006
One year after discharge (end Incidence 492 (449-539)/ of 2003)

Up to 8 years (end of 2003), mean 3.5 years

Up to end of 2012 (total 10,272 person-years) (1)

SMR for suicide 22.8 (16.1-32.2);
100,000 patient-years; 694 (618-778) in males and 332 (286-385) in females

$6.1 \%$ died by suicide, crude incidence 1,700 per 100,000 patient-years
Unit of analysis hospitalization, focus on first year after hospitalization; a highrisk period Cohort comprised only inpatients with bipolar disorder, who had attempted suicide at index hospitalization; a high-risk population. in men 16.1 (9.4-27.8), in women 31.8 (20.3-49.8)
A high suicide mortalityarea in Norway
Up to end of 1995 , mean follow-up 10.52 years $(\mathrm{SD} \pm 6.69)$ in men [345 suicides/69,222 personyears], 11.51 years $(S D \pm$ 6.73 ) in women [327 suicides/ 101,393 person-years] Up to end of 2014, median follow-up 3.80 years
Overall 2,883,088 discharges in the First 30 days after discharge Swedish National Patient Register and 3,695 suicides in the Cause of Death Register; 119,948 and 147 with bipolar disorder, respectively
SMR in men 15.0 (13.516.7), SMR in women 22.4 (20.0-24.9)

55 suicides (1.14\%) among 4,844 male patients; 35 suicides (0.44\%) among 8,006 female patients

Suicide rate 1,740 (1,470- Focus in immediate first2,040) per 100,000 patient- month postdischarge years in bipolar disorder suicides, the period with highest risk national quality register, from which they can opt out.

Suicides as part of mortality; SMRs rather than cumulative incidence
Study based on a
*Incidence rates converted to per 100,000 patient years for comparability. SMR, standardized mortality ratio. 
differences in rates between diagnostic groups, and Isometsä et al. (26) found marked differences in temporal patterns of risk between hospitalizations for different types of index episodes among bipolar patients. After the immediate postdischarge weeks, suicide risk generally steeply declines over time, typically reaching level of about fivefold suicide mortality when over five years has passed after the last hospitalization (31). For suicide prevention, this translates into a temporal window of very high risk to which preventive efforts (improving continuity of treatments between settings, monitoring of suicide risk and

TABLE 3 | Risk factors for suicide in mood disorders in Nordic national-level register-based studies.

Unipolar depression

\begin{tabular}{|c|c|c|c|c|c|c|c|c|c|}
\hline & \multirow[b]{2}{*}{ Study design } & \multirow[b]{2}{*}{$\begin{array}{l}\text { Ns of patients } \\
\text { and suicides }\end{array}$} & \multicolumn{7}{|c|}{ Risk factor and adjusted relative risk (with $95 \%$ confidence intervals) } \\
\hline & & & $\begin{array}{c}\text { Male } \\
\text { gender }\end{array}$ & $\begin{array}{l}\text { Preceding } \\
\text { suicide } \\
\text { attempts }\end{array}$ & $\begin{array}{l}\text { Severity of } \\
\text { depression } \\
\text { at baseline }\end{array}$ & $\begin{array}{l}\text { Psychotic } \\
\text { features }\end{array}$ & $\begin{array}{l}\text { Comorbid } \\
\text { substance } \\
\text { abuse }\end{array}$ & Other & Notes \\
\hline \multicolumn{10}{|l|}{ Study } \\
\hline $\begin{array}{l}\text { Høyer } \\
\text { et al. (29) }\end{array}$ & $\begin{array}{l}\text { Postdischarge } \\
\text { suicides (<1y) } \\
\text { of patients with } \\
\text { affective } \\
\text { disorder in } \\
\text { Denmark in } \\
\text { 1994-1995, } \\
\text { matched } \\
\text { controls }\end{array}$ & $\begin{array}{l}135 \text { suicide cases, } \\
135 \text { controls } \\
\text { identified through } \\
\text { the Danish } \\
\text { Psychiatric Central } \\
\text { Register. }\end{array}$ & $\begin{array}{l}\text { (matched } \\
\text { for gender) }\end{array}$ & $\begin{array}{l}\operatorname{IRR} 4.97 \\
(2.40-10.27)\end{array}$ & - & - & - & $\begin{array}{l}\text { Loss of job in }<12 \\
\text { months, IRR } 2.94 \\
(1.16-7.46) ; \\
\text { Clinical improvement } \\
\text { during admission } \\
0.33(0.15-0.74) ; \\
\text { Antidepressant } 0.35 \\
(0.16-0.75)\end{array}$ & $\begin{array}{l}\text { Included } 30 \\
\text { suicides and } \\
30 \text { controls } \\
\text { with bipolar } \\
\text { disorder }\end{array}$ \\
\hline $\begin{array}{l}\text { Suominen } \\
\text { et al. (20) }\end{array}$ & $\begin{array}{l}\text { Prospective } \\
\text { cohort of } \\
\text { Finnish } \\
\text { inpatients } \\
\text { hospitalized for } \\
\text { depression and } \\
\text { attempted } \\
\text { suicide } \\
\text { between 1996- } \\
2003\end{array}$ & $\begin{array}{l}1,820 \text { inpatients in } \\
\text { the National } \\
\text { Hospital Discharge } \\
\text { Register, } \\
106 \text { suicides in } \\
\text { cause of death } \\
\text { register of the } \\
\text { Statistics Finland }\end{array}$ & $\begin{array}{l}\text { HR } 2.04 \\
(1.39-3.03)\end{array}$ & - & $\begin{array}{l}\text { Moderate HR } \\
1.17(0.26- \\
5.29) ; \\
\text { Severe } 3.10 \\
(0.75-12.81)\end{array}$ & $\begin{array}{l}\text { HR } 3.32 \\
(1.95-5.67)\end{array}$ & - & $\begin{array}{l}\text { Antidepressants HR } \\
1.06(0.71-1.58)\end{array}$ & $\begin{array}{l}\text { Cohort } \\
\text { comprised only } \\
\text { inpatients with } \\
\text { depression, } \\
\text { who had } \\
\text { attempted } \\
\text { suicide at } \\
\text { index } \\
\text { hospitalization; } \\
\text { a high-risk } \\
\text { population }\end{array}$ \\
\hline $\begin{array}{l}\text { Nordentoft } \\
\text { et al. (17) }\end{array}$ & $\begin{array}{l}\text { Prospective } \\
\text { study of } \\
\text { incident } \\
\text { suicides among } \\
\text { Danes born } \\
\text { 1955-1991 to } \\
\text { end of } 2006\end{array}$ & $\begin{array}{l}46,233 \text { mental } \\
\text { health patients with } \\
\text { depression in the } \\
\text { Danish Psychiatric } \\
\text { Central Register, } \\
709 \text { suicides in the } \\
\text { Danish Registers of } \\
\text { Causes of Death }\end{array}$ & $\begin{array}{l}\text { Cumulative } \\
\text { incidence } \\
6.67 \% \\
(5.72-7.78) \\
\text { in men, vs. } \\
3.77 \% \\
\text { (3.05-4.66) } \\
\text { in women }\end{array}$ & $\begin{array}{l}\text { Cumulative } \\
\text { incidence } \\
10.48 \% \\
(8.24-13.32) \\
\text { in men, } \\
6.51 \%(5.23- \\
8.09) \text { in } \\
\text { women }\end{array}$ & - & - & $\begin{array}{l}\text { Cumulative } \\
\text { incidence } \\
6.74 \% \\
(5.24-8.67) \\
\text { in men, } \\
7.12 \% \\
(4.68-10.83) \\
\text { in women }\end{array}$ & - & $\begin{array}{l}\text { Out-patient } \\
\text { visits included } \\
\text { from } 1995 \text { to } \\
2006\end{array}$ \\
\hline $\begin{array}{l}\text { Leadholm } \\
\text { et al. (18) }\end{array}$ & $\begin{array}{l}\text { Prospective } \\
\text { cohort of } \\
\text { Danish in- } \\
\text { patients with } \\
\text { severe } \\
\text { psychotic (PD) } \\
\text { or } \\
\text { nonpsychotic } \\
\text { (non-PD) } \\
\text { depression }\end{array}$ & $\begin{array}{l}34,671 \text { in- or out- } \\
\text { patients in the } \\
\text { Danish Central } \\
\text { Psychiatric } \\
\text { Register, } \\
755 \text { suicides in the } \\
\text { Danish Cause of } \\
\text { Death Register }\end{array}$ & $\begin{array}{l}\text { non-PD } \\
\text { AOR 1.89, } \\
\text { PD AOR } \\
1.98\end{array}$ & $\begin{array}{l}\text { non-PD AOR } \\
5.02, \text { PD } \\
\text { AOR } 5.17\end{array}$ & - & $\begin{array}{l}2.1 \% \\
\text { nonpsychotic } \\
\text { vs. } \\
2.3 \% \\
\text { psychotic } \\
\text { depression; } \\
\text { AOR } 0.97 \\
(0.83-1.15)\end{array}$ & - & $\begin{array}{l}\text { Age at diagnosis PD } \\
\text { AOR 1.1 (1.0-1.1); } \\
\text { non-PD 1.0 (1.0-1.1) }\end{array}$ & $\begin{array}{l}\text { Focus in } \\
\text { severe } \\
\text { depression } \\
\text { and role of } \\
\text { psychotic } \\
\text { features for } \\
\text { risk of suicide }\end{array}$ \\
\hline $\begin{array}{l}\text { Aaltonen } \\
\text { et al. (30) }\end{array}$ & $\begin{array}{l}\text { Prospective } \\
\text { cohort of first- } \\
\text { time inpatients } \\
\text { with depression } \\
\text { in 1991-2011 } \\
\text { in Finland }\end{array}$ & $\begin{array}{l}56,826 \text { inpatients in } \\
\text { the Finnish Hospital } \\
\text { Discharge Register, } \\
\text { linked with Census } \\
\text { Register of Statistics } \\
\text { Finland, and with } \\
2,587 \text { suicides in } \\
\text { Statistic Finland's } \\
\text { register on causes } \\
\text { of death. }\end{array}$ & $\begin{array}{l}\text { AHR } 2.07 \\
(1.91-2.24)\end{array}$ & $\begin{array}{l}\text { At admission } \\
\text { AHR 2.110 } \\
(1.862- \\
2.391) ; \\
\text { previous } 4 \\
\text { years AHR } \\
2.111(1.845- \\
2.415)\end{array}$ & $\begin{array}{l}\text { Severe vs. } \\
\text { moderate } \\
\text { AHR 1.188 } \\
(1.083-1.303)\end{array}$ & $\begin{array}{l}\text { Psychotic vs. } \\
\text { moderate } \\
\text { AHR } 1.451 \\
(1.301-1.619)\end{array}$ & $\begin{array}{l}\text { Alcohol } \\
\text { dependence } \\
\text { AHR 1.261 } \\
(1.129- \\
1.409)\end{array}$ & $\begin{array}{l}\text { Tertiary vs basic } \\
\text { education AHR } \\
1.295 \text { (1.160-1.445); } \\
\text { Highest vs. lowest } \\
\text { income AHR 1.191 } \\
\text { (1.068-1.329); } \\
\text { Living alone AHR } \\
1.124 \text { (1.029-1.227) }\end{array}$ & $\begin{array}{l}\text { Follow-up to } \\
\text { maximum } 24 \\
\text { years. Suicide } \\
\text { mortality } \\
\text { halved } \\
\text { between } 1991 \\
\text { and } 1995 \text { vs. } \\
2006 \text { and } \\
2011\end{array}$ \\
\hline
\end{tabular}


TABLE 3 | Continued

Bipolar Disorder

\begin{tabular}{|c|c|c|c|c|c|c|c|c|c|}
\hline & \multirow[b]{2}{*}{ Study design } & \multirow[b]{2}{*}{$\begin{array}{l}\text { Ns of patients } \\
\text { and suicides }\end{array}$} & \multicolumn{7}{|c|}{ Risk factor and adjusted relative risk (with $95 \%$ confidence intervals) } \\
\hline & & & $\begin{array}{c}\text { Male } \\
\text { gender }\end{array}$ & $\begin{array}{l}\text { Preceding } \\
\text { suicide } \\
\text { attempts }\end{array}$ & $\begin{array}{l}\text { Severity of } \\
\text { depression } \\
\text { at baseline }\end{array}$ & $\begin{array}{l}\text { Psychotic } \\
\text { features }\end{array}$ & $\begin{array}{c}\text { Comorbid } \\
\text { substance } \\
\text { abuse }\end{array}$ & Other & Notes \\
\hline \multicolumn{10}{|l|}{ Study } \\
\hline $\begin{array}{l}\text { Nordentoft } \\
\text { et al. (17) }\end{array}$ & $\begin{array}{l}\text { Prospective } \\
\text { study of } \\
\text { incident } \\
\text { suicides among } \\
\text { Danes born } \\
\text { 1955-1991 to } \\
\text { end of } 2006\end{array}$ & $\begin{array}{l}5,927 \text { mental } \\
\text { health patients } \\
\text { with bipolar } \\
\text { disorder in the } \\
\text { Danish Psychiatric } \\
\text { Central Register, } \\
175 \text { suicides in the } \\
\text { Danish Registers of } \\
\text { Causes of Death }\end{array}$ & $\begin{array}{l}\text { Cumulative } \\
\text { incidence } \\
7.77 \% \\
(6.01- \\
10.05) \text { in } \\
\text { men, vs. } \\
4.78 \% \\
(3.48-6.56) \\
\text { in women }\end{array}$ & $\begin{array}{l}\text { Cumulative } \\
\text { incidence } \\
17.08 \% \\
(11.19-26.07) \\
\text { in men, vs. } \\
9.39 \%(6.07- \\
14.54) \text { in } \\
\text { women }\end{array}$ & & & $\begin{array}{l}\text { Cumulative } \\
\text { incidence } \\
10.01 \% \\
(6.40-15.66) \\
\text { in men, vs. } \\
5.20 \% \\
(2.81-9.60) \\
\text { in women }\end{array}$ & & $\begin{array}{l}\text { Out-patient } \\
\text { visits included } \\
\text { from } 1995 \text { to } \\
2006\end{array}$ \\
\hline $\begin{array}{l}\text { Isometsä } \\
\text { et al. (26) }\end{array}$ & $\begin{array}{l}\text { Prospective } \\
\text { cohort of all } \\
\text { hospitalizations } \\
\text { for bipolar } \\
\text { disorder in } \\
\text { Finland in } \\
\text { 1995-2003. }\end{array}$ & $\begin{array}{l}35,946 \\
\text { hospitalizations in } \\
\text { the Finnish } \\
\text { Hospital Discharge } \\
\text { Register, } 129 \\
\text { suicides within } 120 \\
\text { days from } \\
\text { discharge in the } \\
\text { causes of death } \\
\text { register of the } \\
\text { Statistics Finland; } \\
65 \text { after } \\
\text { hospitalization for } \\
\text { depressive, } 28 \\
\text { after mania, } 20 \\
\text { after mixed } \\
\text { episodes }\end{array}$ & $\begin{array}{l}\text { After } \\
\text { depressive } \\
\text { HR } 3.63 \\
(2.12-6.23)\end{array}$ & $\begin{array}{l}\text { After } \\
\text { depressive } \\
\text { HR } 8.05 \\
\text { (2.49-26.04) } \\
\text { for attempts } \\
\text { at index } \\
\text { hospitalization }\end{array}$ & $\begin{array}{l}\text { Depressive }> \\
\text { mixed }> \\
\text { manic }>\text { other } \\
\text { index } \\
\text { hospitalization }\end{array}$ & & & $\begin{array}{l}\text { After depressive } \\
\text { hospitalization HR for } \\
\text { lithium } 0.186(0.07- \\
\text { 0.52) }\end{array}$ & \\
\hline $\begin{array}{l}\text { Hansson } \\
\text { et al. (28) }\end{array}$ & $\begin{array}{l}\text { Prospective } \\
\text { cohort study } \\
\text { based on the } \\
\text { Swedish } \\
\text { National Quality } \\
\text { Register for } \\
\text { Bipolar } \\
\text { Affective } \\
\text { Disorder } \\
\text { (BipoläR) and } \\
\text { suicide deaths } \\
\text { in 2004-2014. }\end{array}$ & $\begin{array}{l}12,850 \text { bipolar out- } \\
\text { patients in the } \\
\text { BipoläR, } 90 \\
\text { suicides in Cause } \\
\text { of Death Register }\end{array}$ & $\begin{array}{l}\text { Hazard } \\
\text { ratio } 2.56 \\
(1.68-3.92)\end{array}$ & $\begin{array}{l}\mathrm{HR} 4.10 \\
(2.43-6.92)\end{array}$ & $\begin{array}{l}\text { Any affective } \\
\text { episode in } \\
\text { the previous } \\
\text { year HR } 2.39 \\
(1.47-3.88) ; \\
\text { any } \\
\text { depressive } \\
\text { episode in } \\
\text { the previous } \\
\text { year HR 2.24 } \\
\text { (1.25-4.01) }\end{array}$ & & $\begin{array}{l}\text { Comorbid } \\
\text { substance } \\
\text { use disorder } \\
\text { HR } 3.79 \\
(2.21-6.50)\end{array}$ & $\begin{array}{l}\text { Living alone HR } 2.45 \\
\text { (1.36-4.43); criminal } \\
\text { conviction HR } 4.43 \\
\text { (1.35-14.53); any } \\
\text { comorbid psychiatric } \\
\text { disorder HR } 2.64 \\
\text { (1.69-4.13); } \\
\text { comorbid anxiety } \\
\text { disorder HR } 1.91 \\
\text { (1.07-3.42); } \\
\text { psychiatric inpatient } \\
\text { care HR 2.79 (1.62- } \\
\text { 4.80); involuntary } \\
\text { commitment HR } 3.50 \\
\text { (1.71-7.15). }\end{array}$ & $\begin{array}{l}\text { Study based } \\
\text { on a national } \\
\text { quality register, } \\
\text { from which } \\
\text { they can opt } \\
\text { out. }\end{array}$ \\
\hline
\end{tabular}

IRR, incidence rate ratio; HR, hazard ratio; AHR, adjusted hazard ratio; OR, odds ratio; AOR, adjusted odds ratio.

safety planning), need to be focused. However, it is somewhat surprising, that despite this well-known high-risk period and availability of large-scale data, short-term risk factors during this period have remained largely uncharted. Almost all studies focus on risk factors during long-term follow-up. They may or may not be similar.

\section{Risk Factors and the Role of Gender}

In these Nordic studies of depression, long-term risk of suicide was found markedly higher among males than females, those with preceding suicide attempts, high severity of depression at outset of illness, or concurrent substance abuse at baseline. The finding of males with depression having higher risk for suicide than females is fully consistent with the broader suicide literature. The Finnish national study by Aaltonen et al. (30) is the largest of the depression studies, and was large enough to compare potency and prevalence of thirteen risk factors between genders. The observed gender differences were found unremarkable, whereas differences lethal methods pronounced, making them the likely explanation for the higher male suicide mortality in mood disorders. Although rate of suicide in bipolar disorder was recorded in multiple studies, those or risk factors 
for suicide in it were scarce. The three studies $(17,26,28)$ which investigated risk factors for suicide in bipolar disorder generally found male gender, preceding suicide attempts, and occurrence or hospitalization for depressive episodes to be associated with risk. The quality register-based Swedish study (28) found no difference in risk between types of bipolar disorder, but documented risk related to any types of comorbid disorders, living alone and criminal convictions.

\section{Previous Attempts as Indicators of High Risk}

A nonfatal suicide attempt is the strongest known indicator of suicide risk. Therefore, it is unsurprising, that a preceding suicide attempt emerged as a very strong predictor of suicide among patients with mood disorders. The trajectories of higher risk seemed to persist over time. The clinical importance of this highly consistent finding is obvious, as the cumulative incidence of suicides, particularly among males, approached $20 \%$ at worst $(17,30)$. However, to some extent these findings may be inflated by methodological factors, as information on all lifetime suicide attempts is usually unavailable, and only on those severe enough to result into hospital treatment, and temporally associated with the index hospitalization or the few preceding years is known. Methodological differences between studies in these factors are also likely to explain differences in observed findings. Since use of violent methods may involve much higher risk of future suicide death than overdoses (33-35), future studies should also examine risk based on the method used in the preceding nonfatal attempts.

\section{Role of Illness Severity}

Risk of suicide in mood disorders is related to severity of illness. Patients with severe or psychotic illness had higher risk of suicide, and this higher risk persists for years or even decades. It is important to note, that this is true even though information was almost always available only for severity of the first index or baseline episode. Severity of subsequent episodes, not to speak of state of illness at the time of death remained obscure. However, psychological autopsy studies of patients with depression generally find suicides to occur at a time when a depressive episode is ongoing (36), and clinical studies of suicide attempts among depressive patients find suicidal acts to cluster in illness episodes (37-39). It is therefore credible although uncertain, that suicides among depressive patients occur during depressive episodes. Higher severity or psychotic features at index episodes may predict not only similarity of future episodes (40), but also higher rate of recurrences and chronicity of illness, i.e. more time at high-risk clinical states over time (41). However, although patients with psychotic features have highest risk for suicide among those with depression, this is probably due to the higher severity of depressive symptoms overall, rather than psychotic features per se $(18,20,30)$. In these register-based studies, there are only small differences in observed risk between severe nonpsychotic and psychotic depression. Whether more accurate and episode-specific analyses will demonstrate differences in risk remains to be solved by future studies.

\section{Limitations of Register-Based Studies}

Although these findings are based on population studies rather than samples and likely very generalizable beyond the Nordic countries to other countries and settings, it is also important to understand the context and important limitations of register-based studies in study of suicide, in particular crudeness of the data available. Most (75\%) of the studies reviewed comprises exclusively in-patient populations, which are known to represent tip of the iceberg in clinical epidemiology (42). Therefore, rates of suicide are likely to be overestimate rates compared with outpatient settings. All the measures in a national register are based on routine clinical evaluations, accuracy of which may be variable. In most cases, this likely results in random measurement errors, which will deflate subgroup differences. Furthermore, in most of the longitudinal studies data on individuals' characteristics is collected from the life situation at the time of study baseline, whereas situation at the time of suicide at the time of death remains obscure. The paradoxical findings of higher income, education or being married and employed as predictors for suicide among psychiatric patients with mood disorders in the Nordic settings are likely explained by later losses, which remain unknown. The Danish study of individual trajectories by Agerbo (43) clarified such paradoxical findings by demonstrating, that it is precisely loss of these characteristics over time, which is related to suicide risk. Generalizability of these findings to other countries need to be investigated, as e.g. employment, education and income may be more important determinants of access to treatment outside the Nordic countries. Overall, generalizability of all the findings of these Nordic studies to other countries needs to be carefully examined.

The crudeness of register data is revealed by comparing it with comprehensive clinical-epidemiological studies. For example, the reported rates of psychiatric comorbidity are minimal in register data compared with such clinical cohorts $(44,45)$. Since information on longitudinal course of illness is usually totally missing, the remarkably strong association of clinical state, i.e. presence or absence of illness episodes with suicidal acts (37-39) remains unobserved. Furthermore, with only a few exceptions (30), register-based studies cover only a few of the tens of putative risk factors in depression (6), and large-scale studies informing risk factors related to suicide deaths in bipolar disorder are scarce (7), particularly pertaining type II. A noteworthy exception and perhaps a harbinger of future epidemiology is the relative richness of data in the Swedish bipolar quality register BipoläR (28). Overall, currently available register-based studies are important in providing epidemiologically credible estimates of total suicide risk over time among those most ill, and generalizable information on some easilyobserved and temporally static risk factors, but not a complete picture of the numerous factors influencing suicide risk.

\section{Past Decades vs. Current Treatment Settings}

It is important also to note the differences in time periods covered between the studies. Several of the included studies covered time from 1970s onwards, as from that time register data is available. However, studies from the 1970s and 1980s cover a quite different era of treatments and service provision. In 11 of the 16 studies 
included into the Tables the follow-up reached the current millennium, and only five $(19,21,22,28,30)$ the 2010 s, latest up to 2014 (28). It is unavoidable, that long-term follow-up studies cover past decades, but there is also a significant delay in updating register-based datasets. As Aaltonen et al. (21) verified, besides the general decline in suicide rates in the Nordic countries, specifically also the suicide mortality of in patients with depression has halved at least in Finland from the 1990s to the 2010s. Thus, the suicide mortality estimates reported here most likely exceed current realities, and the degree to which the architecture of risk factors has changed over time along with societal changes and changes in treatment and their provision remains an important future research topic. Obviously, there is a great need to update the current knowledge base.

\section{Future Prospects: Electronic Health Records, Quality Registers, and Big Data}

Health care records are undergoing transformation, and electronic records and quality registers (see ref. (28) may in the future contain an order of magnitude richer source of data for monitoring treatment quality, outcome and suicide research. In particular, availability of repeated symptom scores plus trait measures concurrently with updated information on family

\section{REFERENCES}

1. Naghavi MGlobal Burden of Disease Self-Harm Collaborators. Global, regional, and national burden of suicide mortality 1990 to 2016: systematic analysis for the Global Burden of Disease Study 2016. BMJ (2019) 364:194. doi: 10.1136/bmj.194

2. Cavanagh JT, Carson AJ, Sharpe M, Lawrie SM. Psychological autopsy studies of suicide: a systematic review. Psychol Med (2003) 33(3):395-405. doi: $10.1017 /$ S0033291702006943

3. Arsenault-Lapierre G, Kim C, Turecki G. Psychiatric diagnoses in 3275 suicides: a meta-analysis. BMC Psychiatry (2004) 4:37. doi: 10.1186/1471244X-4-37

4. Conner KR, Bridge JA, Davidson DJ, Pilcher C, Brent DA. Metaanalysis of Mood and Substance Use Disorders in Proximal Risk for Suicide Deaths. Suicide Life Threat Behav (2019) 49(1):278-92. doi: 10.1111/sltb.12422

5. Cho SE, Na KS, Cho SJ, Im JS, Kang SG. Geographical and temporal variations in the prevalence of mental disorders in suicide: Systematic review and meta-analysis. J Affect Disord (2016) 190:704-13. doi: 10.1016/ j.jad.2015.11.008

6. Isometsä E. Suicidal behavior in mood disorders - who, when and why? Can J Psychiatry (2014) 59:120-30. doi: 10.1177/070674371405900303

7. Hawton K, Casañas I Comabella C, Haw C, Saunders K. Risk factors for suicide in individuals with depression: a systematic review. J Affect Disord (2013) 147(1-3):17-28. doi: 10.1016/j.jad.2013.01.004

8. Schaffer A, Isometsä ET, Tondo L, Moreno D, Turecki G, Reis C, et al. International Society for Bipolar Disorders Task Force on Suicide: Metaanalyses and Meta-Regression of Correlates of Suicide Attempts and Suicide Deaths in Bipolar Disorder. Bipolar Disord (2015) 17:1-16. doi: 10.1111/ bdi.12271

9. Goodwin FK, Jamison KR. Manic-Depressive Illness. New York: Oxford University Press (1990).

10. Bostwick JM, Pankratz VS. Affective disorders and suicide risk: a reexamination. Am J Psychiatry (2000) 157:1925-32. doi: 10.1176/ appi.ajp.157.12.1925

11. Erlangsen A, Qin P, Mittendorfer-Rutz E. Studies of Suicidal Behavior Using National Registers. Crisis (2018) 39(3):153-8. doi: 10.1027/0227-5910/a000552 situation and employment will result in more accurate view of factors influencing suicide risk (46-48). More sophisticated machine learning tools may be helpful in uncovering previously unobserved patterns related to risk, but statistical rarity of suicide will unavoidably limit predictive ability also in the future, irrespective of sophistication of analytical tools (49). Coverage plus validity and uniformity of measures across settings will be central issues for utility of data. Availability of such data will hopefully advance efforts to prevent suicides among patients suffering from mood disorders.

\section{DATA AVAILABILITY STATEMENT}

The original contributions presented in the study are included in the article/supplementary materials; further inquiries can be directed to the corresponding author.

\section{AUTHOR CONTRIBUTIONS}

The author confirms being the sole contributor of this work and has approved it for publication.

12. Nordic Burden of Disease Collaborators. Life expectancy and disease burden in the Nordic countries: results from the Global Burden of Diseases, Injuries, and Risk Factors Study 2017. Lancet Public Health (2019) 4(12):e658-69. doi: 10.1016/S2468-2667(19)30224-5

13. Nordentoft M, Wahlbeck K, Hällgren J Westman J, Ösby U, Alinaghizadeh H, Gissler M, et al. Excess mortality, causes of death and life expectancy in 270,770 patients with recent onset of mental disorders in Denmark, Finland and Sweden. PLoS One (2013) 8:e55176. doi: 10.1371/journal.pone.0055176

14. Nordic Medico-Statistical Committee. Health Statistics for the Nordic Countries 2017. Copenhagen: Nomesco p. 108, (2017).

15. Høyer EH, Mortensen PB, Olesen AV. Mortality and causes of death in a total national sample of patients with affective disorders admitted for the first time between 1973 and 1993. Br J Psychiatry (2000) 176:76-82. doi: 10.1192/ bjp.176.1.76

16. Qin P, Nordentoft M. Suicide risk in relation to psychiatric hospitalization: evidence based on longitudinal registers. Arch Gen Psychiatry (2005) 62 (4):427-32. doi: 10.1001/archpsyc.62.4.427

17. Nordentoft M, Mortensen PB, Pedersen CB. Absolute risk of suicide after first hospital contact in mental disorder. Arch Gen Psychiatry (2011) 68(10):105864. doi: 10.1001/archgenpsychiatry.2011.113

18. Leadholm AK, Rothschild AJ, Nielsen J, Bech P, Ostergaard SD. Risk factors for suicide among 34,671 patients with psychotic and non-psychotic severe depression. J Affect Disord (2014) 156:119-25. doi: 10.1016/j.jad.2013.12.003

19. Laursen TM, Musliner KL, Benros ME, Vestergaard M, Munk-Olsen T. Mortality and life expectancy in persons with severe unipolar depression. J Affect Disord (2016) 193:203-7. doi: 10.1016/j.jad.2015.12.067

20. Suominen K, Haukka J, Valtonen HM, Lönnqvist J. Outcome of patients with major depressive disorder after serious suicide attempt. J Clin Psychiatry (2009) 70(10):1372-8. doi: 10.4088/JCP.09m05110blu

21. Aaltonen KI, Isometsä E, Sund R, Pirkola S. Decline in suicide mortality after psychiatric hospitalization for depression in Finland between 1991 and 2014 World Psychiatry (2018) 17(1):110-2. doi: 10.1002/wps.20501

22. Høye A, Nesvåg R, Reichborn-Kjennerud T, Jacobsen BK. Sex differences in mortality among patients admitted with affective disorders in North Norway: a 33-year prospective register study. Bipolar Disord (2016) 18(3):272-81. doi: 10.1111/bdi.12389 
23. Ösby U, Brandt L, Correia N, Ekbom A, Sparén P. Excess mortality in bipolar and unipolar disorder in Sweden. Arch Gen Psychiatry (2001) 58(9):844-50. doi: 10.1001/archpsyc.58.9.844

24. Tidemalm D, Långström N, Lichtenstein $P$, Runeson B. Risk of suicide after suicide attempt according to coexisting psychiatric disorder: Swedish cohort study with long term follow-up. BMJ (2008) 337:a2205. doi: 10.1136/bmj.a2205

25. Haglund A, Lysell H, Larsson H, Lichtenstein P, Runeson B. Suicide Immediately After Discharge From Psychiatric Inpatient Care: A Cohort Study of Nearly 2.9 Million Discharges. J Clin Psychiatry (2019) 80(2):pii: 18m12172. doi: $10.4088 / J C P .18 \mathrm{~m} 12172$

26. Isometsä E, Sund R, Pirkola S. Post-discharge suicides of inpatients with bipolar disorder in Finland. Bipolar Disord (2014) 16(8):867-74. doi: 10.1111/ bdi. 12237

27. Toffol E, Hätönen T, Tanskanen A, Lönnqvist J, Wahlbeck K, Joffe G, et al. Lithium is associated with decrease in all-cause and suicide mortality in highrisk bipolar patients: A nationwide registry-based prospective cohort study. J Affect Disord (2015) 183:159-65. doi: 10.1016/j.jad.2015.04.055

28. Hansson C, Joas E, Pålsson E, Hawton K, Runeson B, Landén M. Risk factors for suicide in bipolar disorder: a cohort study of 12850 patients. Acta Psychiatr Scand (2018) 138(5):456-63. doi: 10.1111/acps.12946

29. Høyer EH, Licht RW, Mortensen PB. Risk factors of suicide in inpatients and recently discharged patients with affective disorders. A case-control study. Eur Psychiatry (2009) 24(5):317-21. doi: 10.1016/j.eurpsy.2008.03.011

30. Aaltonen KI, Isometsä E, Sund R, Pirkola S. Risk factors for suicide in depression in Finland: first-hospitalized patients followed up to 24 years. Acta Psychiatr Scand (2019) 139(2):154-63. doi: 10.1111/acps.12990

31. Chung DT, Ryan CJ, Hadzi-Pavlovic D, Singh SP, Stanton C, Large MM. Suicide Rates After Discharge From Psychiatric Facilities: A Systematic Review and Meta-analysis. JAMA Psychiatry (2017) 74(7):694-702. doi: 10.1001/jamapsychiatry.2017.1044

32. Chung D, Hadzi-Pavlovic D, Wang M, Swaraj S, Olfson M, Large M. Meta-analysis of suicide rates in the first week and the first month after psychiatric hospitalisation. BMJ Open (2019) 9(3):e023883. doi: 10.1136/bmjopen-2018-023883

33. Runeson B, Tidemalm D, Dahlin M, Lichtenstein P, Långström N. Method of attempted suicide as predictor of subsequent successful suicide: national long term cohort study. BMJ (2010) 341:c3222. doi: 10.1136/bmj.c3222

34. Bergen H, Hawton K, Waters K, Ness J, Cooper J, Steeg S, et al. How do methods of non-fatal self-harm relate to eventual suicide? J Affect Disord (2012) 136(3):526-33. doi: 10.1016/j.jad.2011.10.036

35. Olfson M, Wall M, Wang S, Crystal S, Gerhard T, Blanco C. Suicide Following Deliberate Self-Harm. Am J Psychiatry (2017) 174(8):765-74. doi: 10.1176/ appi.ajp.2017.16111288

36. Isometsä E. Psychological autopsy studies - a review. Eur Psychiatry (2001) 16:379-85. doi: 10.1016/S0924-9338(01)00594-6

37. Holma KM, Melartin TK, Haukka J, Holma IA, Sokero TP, Isometsä ET. Incidence and predictors of suicide attempts in DSM-IV major depressive disorder: a five-year prospective study. Am J Psychiatry (2010) 167:801-8. doi: 10.1176/appi.ajp.2010.09050627

38. Holma M, Haukka J, Suominen K, Valtonen HM, Mantere O, Melartin TK, et al. Differences in incidence of suicide attempts between bipolar I and II disorders and major depressive disorder. Bipolar Disord (2014) 16:652-61. doi: 10.1111/bdi.12195
39. Pallaskorpi S, Suominen K, Ketokivi M, Valtonen H, Arvilommi P, Mantere $\mathrm{O}$, et al. Incidence and predictors of suicide attempts in bipolar I and II disorders: A 5-year follow-up study. Bipolar Disord (2017) 19:13-22. doi: 10.1111/bdi.12464

40. Nelson JC, Bickford D, Delucchi K, Fiedorowicz JG, Coryell WH. Risk of Psychosis in Recurrent Episodes of Psychotic and Nonpsychotic Major Depressive Disorder: A Systematic Review and Meta-Analysis. Am J Psychiatry (2018) 175(9):897-904. doi: 10.1176/appi.ajp.2018.17101138

41. Holma KM, Holma IA, Melartin TK, Rytsälä HJ, Isometsä ET. Long-term outcome of major depressive disorder in psychiatric patients is variable. J Clin Psychiatry (2008) 69:196-205. doi: 10.4088/JCP.v69n0205

42. Walby FA, Myhre MØ, Kildahl AT. Contact With Mental Health Services Prior to Suicide: A Systematic Review and Meta-Analysis. Psychiatr Serv (2018) 69(7):751-9. doi: 10.1176/appi.ps.201700475

43. Agerbo E. High income, employment, postgraduate education, and marriage: a suicidal cocktail among psychiatric patients. Arch Gen Psychiatry (2007) 64 (12):1377-84. doi: 10.1001/archpsyc.64.12.1377

44. Melartin TK, Rytsälä HJ, Leskelä US, Lestelä-Mielonen PS, Sokero TP, Isometsä ET. Current comorbidity of psychiatric disorders among DSM-IV major depressive disorder patients in psychiatric care in the Vantaa Depression Study. J Clin Psychiatry (2002) 63:126-34. doi: 10.4088/ JCP.v63n0207

45. Mantere O, Suominen K, Melartin T, Valtonen H, Arvilommi P, Leppämäki S, et al. Differences in patterns of axis I and II comorbidity of bipolar I vs. II vs. major depressive disorders. J Clin Psychiatry (2006) 67:584-93. doi: 10.4088/ JCP.v67n0409

46. Simon GE, Johnson E, Lawrence JM, Rossom RC, Ahmedani B, Lynch FL, et al. Predicting Suicide Attempts and Suicide Deaths Following Outpatient Visits Using Electronic Health Records. Am J Psychiatry (2018) 175(10):95160. doi: 10.1176/appi.ajp.2018.17101167

47. Simon GE, Yarborough BJ, Rossom RC, Lawrence JM, Lynch FL, Waitzfelder BE, et al. Self-Reported Suicidal Ideation as a Predictor of Suicidal Behavior Among Outpatients With Diagnoses of Psychotic Disorders. Psychiatr Serv (2019) 70(3):176-83. doi: 10.1176/appi.ps.201800381

48. Gong J, Simon GE, Liu S. Machine learning discovery of longitudinal patterns of depression and suicidal ideation. PLoS One (2019) 14(9):e0222665. doi: 10.1371/journal.pone.0222665.

49. Belsher BE, Smolenski DJ, Pruitt LD, Bush NE, Beech EH, Workman DE, et al. Prediction Models for Suicide Attempts and Deaths: A Systematic Review and Simulation. JAMA Psychiatry (2019) 76(6):642-51. doi: 10.1001/ jamapsychiatry.2019.0174

Conflict of Interest: The author declares that the work was conducted in the absence of any commercial or financial relationships that could be construed as a potential conflict of interest.

Copyright $(\odot) 2020$ Isometsä. This is an open-access article distributed under the terms of the Creative Commons Attribution License (CC BY). The use, distribution or reproduction in other forums is permitted, provided the original author(s) and the copyright owner(s) are credited and that the original publication in this journal is cited, in accordance with accepted academic practice. No use, distribution or reproduction is permitted which does not comply with these terms. 